\title{
Lecturas hermenéuticas de la mujer en arte/comunicación/cultura. El caso del Friso de Beethoven de Gustav Klimt
}

\author{
Hermeneutic readings of women in \\ art / communication / culture. The case of the \\ Beethoven Frieze by Gustar Klimt
}

Ana Laura Hidalgo

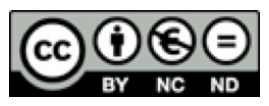

Esta obra está bajo una licencia Creative Commons Reconocimiento-No comercial-Sin Obra Derivada 


\title{
Lecturas hermenéuticas de la mujer en arte/comunicación/cultura. El caso del Friso de Beethoven de Gustav Klimt Hermeneutic readings of women in art / communication / culture. The case of the Beethoven Frieze by Gustav Klimt
}

\author{
Ana Laura Hidalgo ${ }^{1}$ \\ Universidad Nacional de San Luis (UNSL) \\ hidalgo.analaura@gmail.com
}

Recibido: 7 de marzo de 2017 Aprobado: 22 de mayo de 2017

\section{Resumen}

Este trabajo se propone realizar una mirada acerca del Friso de Beethoven (1902) desde la hermenéutica filosófica, a fin de vincular las nociones de arte, comunicación y cultura desde un horizonte de sentido posible que aborde la mujer. Las primeras preguntas se orientan hacia la noción de Gesamtkunstwerk de la puesta klimtiana de la XIV Exposición de la Secesión Vienesa desde relecturas de la Escuela de Frankfurt. Posteriormente, el trabajo explora las exposiciones secesionistas y la muestra del año 1902. A continuación, se detiene en las mujeres creadas en el Friso de Beethoven, a fin de favorecer diálogos entre la industria cultural, la cultura de masas y lo femenino. A fin de recrear los impulsos estéticos que movilizaron el grupo secesionista en el corpus de estudio, el presente artículo se organiza siguiendo los momentos de una ópera: Obertura, Actos y Escenas.

Palabras claves: arte; comunicación; cultura; hermenéutica; mujer

1 Magister en Política y Planificación Social y Especialista en Gestión Social por la Universidad Nacional de Cuyo y Doctoranda en Ciencias Sociales por la Universidad de Buenos Aires. Docente investigadora de la Universidad Nacional de San Luis. Becaria Doctoral de CONICET. 


\begin{abstract}
This paper intends to expose a look about Beethoven's Frieze (1902) from a philosophical hermeneutic interpretation, in order to link the notions of art, communication and culture from a horizon of possible sense. The first questions are geared towards the notion of Gesamtkunstwerk of klimtiana start of the XIV Exhibition of Vienna Secession. Subsequently, work stops in the feminine and the woman is created, in order to foster dialogue between the culture industry, mass culture and feminine. The purpose of this paper is to present one of many possible interpretations of the works of Gustav Klimt. To recreate the pulses esthetic that mobilized the secessionist group in this studies, this article is organized along the opera's moments: Overture, Acts, Intermezzos.
\end{abstract}

Keys Words: art; communication; culture; hermeneutics; women 


\section{Obertura}

En este trabajo se presenta un intento por poner en diálogo diversas tradiciones en una fusión interdisciplinaria de las nociones de arte, comunicación y cultura, a fin de indagar en la Gesamtkunstwerk2 de la puesta klimtiana de 1902, el Friso de Beethoven. Fundamentalmente, se recupera la figura de mujer que se ha construido en su interior; uno de los temas privilegiados de este artista austriaco. Al mismo tiempo, se esboza una primera aproximación a las vinculaciones entre la industria de la cultura: la cultura de masas y lo femenino. A partir de allí, se habilita a pensar en la contingencia de lo bello, noción identificada como la experiencia hermenéutica de nuestro presente, según la hermenéutica filosófica (Gadamer, 1998).

La experiencia de lo bello, además, no excluye la consideración de otros factores que constituyen la obra de arte: su mercantilización, la esterotipación de sus formas puestas en las texturas por medio de la feminización del hombre y la varonización de la mujer, entre otras cuestiones. Por ello, se aborda la experiencia del arte en este registro hermenéutico desde la ontología de la obra de arte (Gadamer, 1998, 2004, 2006) como así también desde la ontología histórica de nosotros mismos (Agamben, 2008; Foucault 1998, 2008, 2009), por desarrollarse en el umbral de ambas teorías una interpretación del hombre como subjetividad constituida histórica, estética y culturalmente, y en el horizonte de una mediación de la experiencia de sí como trazado ético y estético de la subjetividad del hombre contemporáneo. Con la intención de recrear la noción de Gesamtkunstwerk -propósito estético de la muestra secesionista para la cual fue creado el Friso de Beethoven-, el recorrido propuesto se organiza siguiendo los momentos de una ópera: Obertura, Actos e Intermezzos.

\section{Acto I. Referencias teóricas}

Trazar los límites en una investigación en comunicación es un proyecto que no carece de controversias. Definir las aristas de sus alcances ha inspirado numerosos estudios a lo largo de la tradición del campo. Por esto, en este trabajo se asume que las investigaciones en comunicación deben superar los discursos que pasan en y por los medios, a fin de nutrir el campo de conocimiento y aportar nuevos debates y búsquedas en los espacios de articulación en el par comunicación/cultura (Schmucler, 1997).

2 Esta palabra alemana puede traducirse como "obra de arte total"; si bien esta expresión no resulta del todo equivalente, será usada atentos a esta salvedad, en su idioma original. 


\section{Escena 1. La filosof ía hermenéutica de Gadamer}

Las creaciones artísticas son existencias de un momento histórico específico y, por tanto, no pueden pensarse sin contemplarse las condiciones socio-culturales que las enmarcan, como así tampoco los discursos anteriores que las posibilitan. Además, permiten ser repensadas en una nueva articulación. Así, de acuerdo con la hermenéutica filosófica, cada lectura de la obra es una nueva creación y constitutiva de un genuino evento ontológico, puesto que es construida desde lo particular. Por tanto, se sostiene que las teorías y nociones no admiten un sentido de una vez y para siempre sino, en cambio, ese círculo interpretativo se crea, recrea y se reactualiza en cada momento; en cada nuevo contexto; en cada nueva lectura. Así, recuperando la tradición hermenéutica de Hans-Georg Gadamer, se considera a toda estructura de sentido como texto y, por tanto, sostiene que "hasta las motivaciones conscientes o inconscientes de la acción humana son susceptibles de interpretación. ... Ningún marco interpretativo es arbitrario ni, menos aún, "objetivo". ... la reflexión hermenéutica demuestra que hay en él unos presupuestos ocultos que son decisivos" (Gadamer, 2004, p. 372). Por tanto, la interpretación debe fusionar ambos horizontes históricos, el del intérprete y del universo de sentido. Esto es posibilitado por el lenguaje en un juego de interpretación único. De este modo, para participar de cualquier intercambio que pretenda inscribirse en uno comunicativo, el sujeto debe compartir el evento de encuentro con el otro más allá de las diferencias espacio-temporales.

Ángel Gabilondo explica en la introducción a Estética y Hermenéutica que, "no se trata de jugar uno con el lenguaje, sino de un juego del propio lenguaje, ya que es más bien el juego mismo el que juega" (Gabilondo en Gadamer, 2006, p. 15). Entonces, participar en él nos permite ser convocados a reconocernos en lo que somos, a participar de la experiencia en que existimos, pero al mismo tiempo supone reconocer esa distancia que nos constituye. Es por ello que con este planteo:

buscamos llegar a acuerdos en la lectura como lo hacemos en la conversación que en definitiva somos. Nos recordamos en aquella. Y así como dialogamos en la tradición (tanto como con ella), en el otro (tanto como en él) y en nosotros mismos (tanto como con nosotros), nos jugamos en el juego (más que con él). La conversación no es instrumento, es método. La comprensión no supone un nuevo entorno a lo común (como si hubiera de accederse a un determinado lugar), sino de lo común, de la participación en ello, esto es, de la comunicación (Gabilondo citado por Gadamer, 2006, p. 16) ${ }^{3}$.

3 Gabilondo continúa explicando por qué esa comunicación no debe ser solo entre nosotros. "Ensanchar y ampliar los límites de lo decible, entre otros aspectos entre las diversas materias y disciplinas, entre las diversas facultades y, en definitiva, en una cierta recomposición en la que la verdad, el bien y la belleza reganen su posición en lo común, en su común sentido (que no se reduce a mero sentido común)" (Gabilondo en Gadamer, 2006, p.16). 
El impulso que reúne estas nociones es el concepto de Gesamtkunstwerk que intenta ponerse de manifiesto en el Friso de Beethoven, una obra compuesta por Gustav Klimt, en 1902; con motivo de la XIV Exposición de la Secession bajo el tema: el "Culto al Artista". Si bien el concepto de Gesamtkunstwerk atraviesa toda la instalación secesionista y la escultura de Max Klinger, en este trabajo solo se considerará parte de la composición klimtiana en relación con la figura de mujer que es construida en la misma. Se trata de una alegoría de treinta y cuatro metros con diferentes episodios simbólicos sobre la salvación de la humanidad a través del arte, inspirados en la interpretación de la Novena Sinfonía de Beethoven que hizo Richard Wagner en 1846. Así como en la poesía de Friedrich Schiller An die Freude, la Gesamtkunstwerk de Wagner pretendía la reunión de todas las artes en un único impulso de expresión y consideraba su realización más plena en la ópera dramática. Puesto que, en ella se implicaban las artes de espacio (arquitectura, escultura y pintura), con las de tiempo (música, poesía y danza) bajo una misma idea estética que permitía ordenar esos impulsos de expresión. ¿Pero, de qué modo se asume al intérprete como contemporáneo de una obra del año 1902?

El trabajo intelectual hermenéutico de Gadamer se expande hacia una filosofía estética. En sus escritos aborda la noción de experiencia estética, en la cual se diluye la dicotomía clásica de las ciencias naturales: la separación entre sujeto y objeto. De este modo, la experiencia estética es para este autor un límite al método consolidado en las ciencias naturales. La obra de arte posibilita la fusión de la historicidad del sujeto creador, del interpretante y del mismo objeto. Esta fusión es la que cuestiona la tradición de las ciencias naturales. En su texto La actualidad de lo bello (1998) el autor trabaja categorías fundamentales para explicar su concepción de experiencia estética.

La noción de juego le permite a Gadamer expresar un vaivén entre el sujeto creador, el sujeto interprete, la historicidad de ambos y la obra. De este modo, el sujeto se rinde a la contemplación de la obra y entra en ese círculo hermenéutico que le permite introducir su propia historicidad en la trama. Por su parte, la experiencia estética es símbolo en tanto permite reconocer a otro, un Ser como fragmento que puede integrarse a un todo que se le corresponda. Finalmente, la experiencia estética no solo rompe la distinción entre sujeto y objeto, sino que también posibilita una variación respecto de la temporalidad, puesto que el sujeto se pierde a sí mismo en contacto con la obra. Esto es recreado por el concepto de fiesta que Gadamer reconoce en la ruptura de la historicidad cotidiana de la temporalidad. Estas nociones le permiten sostener al autor que, luego de una experiencia estética, el sujeto ya no puede volver a ser quien era; toda vez que ese conocimiento proveniente de la misma lo haya condicionado y atravesado. 


\section{Escena 2. Un pensar(nos) con vocación contemporánea}

La construcción de un objeto implica definir un lugar desde el cual situarse respecto del mismo. En este sentido, se recupera la pregunta por la actualidad del presente. Sobre esta problematización, se refiere Agamben (2008) cuando señala la necesidad de ser contemporáneos de los textos y de los autores que se examina; se trata de una actividad más de aquellos animales inteligentes que describió Nietzsche, los cuales un día decidieron inventar el conocimiento, "el minuto más soberbio y falaz de la historia universal" (Nietzsche, 2009, p. 43). "Lo contemporáneo es lo intempestivo" afirma Nietzsche, en el sentido de que permite situar la pretensión de "actualidad", el estar siendo de las cosas en el mundo. Esta noción alude a la posibilidad de contemporaneidad a pesar de los desplazamientos inactuales que se producen, es "aquél que no coincide perfectamente con su tiempo ni se adecua a sus pretensiones, y en este sentido, es inactual" (Vignale, 2010, p. 6). El ser contemporáneo logra percibir y aprisionar(se) en su tiempo, pertenecerle irrevocablemente. Esta vocación de contemporaneidad es, en definitiva, aquel lugar a partir del cual se reconstruyen las nociones de arte, comunicación y cultura en la instalación secesionista. Esto reclama, asimismo, una actitud que permita abordar diversas materialidades significantes en la comprensión de un fenómeno, a fin de posibilitar una fusión horizóntica también, de nosotros mismos (Gadamer, 2004). De este modo, el investigador en cuanto contemporáneo -al igual que el poeta-, debe ser esa fractura que impide al tiempo componerse (Foucault, 1999).

El ser contemporáneo tiene fija la mirada en su tiempo, para percibir la oscuridad y detenerse en ella, pero no con intenciones de pasividad, sino que, implica una actividad y una habilidad particular. Conlleva, asimismo, neutralizar las luces propias de cada época que no son separables de su oscuridad. De este modo, percibir la oscuridad es algo que lo interpela, que se dirige a él de modo especial en tanto que, las luces de su tiempo no pueden alcanzarlo. La contemporaneidad es en el tiempo cronológico, como aquello que urge dentro de él y, por tanto, lo transforma; esa urgencia es la intempestividad (Agamben, 2008). Por esto, la contemporaneidad se inscribe el presente, al tiempo que lo sella como "arcaico", próximo al origen. Un origen que no está situado en el pasado, sino que está siendo y es contemporáneo en el devenir histórico y no cesa de operar en él. La vocación de ser contemporáneos permite desfasar y generar desplazamientos en el tiempo, que posibilita favorecer fusiones horizónticas de sentido en relación con otros. En esa relación con otros, emerge también la pregunta por nosotros mismos (Vignale, 2010). Y como mediación, es también intempestiva, puesto que se intenta "comprender algo de lo que con razón se enorgullece este tiempo, su cultura histórica, como algo perjudicial, como defecto y carencia de esta época" (Nietzsche. 2003, p. 38), al mismo tiempo que lo ahistórico y lo histórico "en igual medida necesarios para la salud de un individuo, de un pueblo o de una cultura" (Nietzsche, 2003, p. 45). 


\section{Escena 3. Hacia una relectura de la Escuela de Frankfurt}

De acuerdo con Grüner (2009), el surgimiento de la Escuela de Frankfurt estuvo marcada por la crítica principalmente, a dos ejes: la reducción formal de la libertad y la igualdad, y la oposición a la masificación degradante del hombre. Por su parte, Huyssen sostiene que, con la emergencia de la sociedad civil, la esfera de la cultura quedó desvinculada del ámbito de los sistemas políticos y económicos. Ya la obra de Kant, había señalado esta escisión propia de la modernidad y como condición de posibilidad de la emergencia de una esfera propia del arte. Pero esta, al mismo tiempo, posibilitó la diferenciación del arte elevado autónomo y la propia de la cultura de masas, ambas ajenas a las esferas políticas y económicas. Huyssen explica esta idea con las siguientes palabras:

Lo irónico es que la aspiración del arte a la autonomía, su desvinculación de la Iglesia y del Estado, solo fue posible cuando la literatura, la pintura y la música se organizaron según los principios de la economía de mercado. Desde sus comienzos la autonomía del arte ha estado dialécticamente ligada a la forma de la mercancía (Huyssen, 2006, p. 42).

Y continúa explicando que la creciente capitalización de la industria por parte de las diferentes manifestaciones artísticas, el desarrollo de un mercado del arte, indica, de algún modo, la dicotomía alto/bajo, acrecentada por los conflictos de clases de mediados del siglo XIX y la irrupción de la Revolución Industrial, que impuso nuevas orientaciones culturales a las masas. De esta forma, la universalización de las mercancías comienza a alcanzar a las masas con un criterio claramente privado, que respondía a la clase capitalista dominante. En este marco, la cultura popular tradicional entra en actitud de resistencia respecto de la cultura industrial, proceso desatado a mediados del siglo XIX.

En este nuevo escenario contextual, Adorno reconoce que la muestra más evidente de triunfo de la ideología dominante es la apariencia de reconciliación de la realidad. Esta realidad logra disolver las particularidades concretas del objeto en las universalidades abstractas del concepto ("pensamiento identitario"). En la industria de la cultura, se reúnen estas características con la denominada "racionalidad instrumental". De este modo, el concepto de industria cultural no es un concepto que pueda explicarse meramente, desde lo económico o sociológico; antes bien, es un constructo teórico filosófico y crítico que se vincula con lo anterior. Tiene un amplio alcance y, desde este sentido, permite pensar todos los aspectos de la modernidad en su conjunto. Principalmente, porque es el producto de una transformación fundamental en la superestructura de las sociedades modernas capitalistas, y penetra en la distinción marxista de economía y cultura como base y superestructura: "el capitalismo del siglo veinte ... ha reunificado la economía y la cultura, subsumiendo lo cultural en lo económico y reorganizando el cuerpo de significados simbólicos y culturales para ajustarlos a la lógica de la mercancía" 
(Huyssen, 2006, p. 49). De este modo, la cultura se estandarizada con el propósito de servir como instrumento de control social. Horkheimer y Adorno empiezan a escribir Dialéctica del Iluminismo en el año 1943, pero se publicará hasta 1947. En pleno "Estado de Bienestar" y en una sociedad caracterizada por su consumo y estimulada a ello, de un modo sin precedentes. En las primeras líneas del capítulo La Industria Cultural se lee:

La cultura marca hoy todo con un rasgo de semejanza. Cine, radio y revistas constituyen un sistema. Cada sector está armonizado en sí mismo y todos entre ellos. Las manifestaciones estéticas, incluso de las posiciones políticas opuestas, proclaman del mismo modo el elogio del ritmo de acero (Horkheimer \& Adorno, 1998, p. 165).

En este sentido, consideran a la Ilustración caracterizada por el cálculo de los efectos y en la técnica de producción y difusión. Mientras que, la ideología se agota en la fetichización de lo existente y del poder que controla la técnica. Con lo anterior, podríamos entender la industria cultural como un sistema productivo de la cultura que crea semejanzas y homogeneización, no necesariamente de objetos y contenidos, sino de la lógica bajo la cual son producidos. Una de las características fundamentales de esta lógica es la mercancía; en quinientos años de capitalismo, los objetos siempre fueron potenciales de ser transformados en mercancías. En cambio, en esta nueva etapa los objetos son pensados y producidos para ser mercancías y en esa forma encuentran su especificidad. Los productos de la cultura son concebidos para que arrojen una ganancia en tanto mercancía, siendo absorbidos por el modo de producción capitalista. Por tanto, este sistema totalitario del capital, abarca todas las prácticas de la llamada industria de producción de objetos culturales.

Esto da lugar a lo que conocemos como "cultura de masas", distinguible de la "cultura popular", que implica la creación espontánea y anónima de una sociedad o grupo. En cambio, la primera es constituida a partir de una planificación de formas culturales mercantiles para el gran consumo de las masas urbanas. Esto es necesariamente producto de la industria cultural; pero no esconde su carácter mercantil, sino que en cambio lo muestra como ideología auto-justificadora: hace de su producto como mercancía, un valor en sí mismo ${ }^{4}$.

Esta lógica de producción es lo que le interesa a Adorno, donde se encuentra la verdadera homogeneidad, no solo en los objetos y en sus contenidos. Todo aparece como distinto, sin embargo, es más de lo mismo; lo mismo de mil modos diferentes. Ahí aparece la libertad de los sujetos, pero es solo una libertad de elección. Adorno sostiene que la lógica del producto

4 Ahora bien, la industria cultural cuenta con su propia lógica de producción de diversificación de la audiencia, e incluso se encarga de diversificarla aún más, algo que en el Marketing se conoce como "segmentación de mercados". 
no se distingue de la lógica de la sociedad de consumo. Entonces únicamente se elige de lo que se ofrece; se adapta la lógica del consumo a la lógica de la producción, y esto borra toda posible huella de espontaneidad en el público. En este sistema totalizador e integrado en el que, se estipula, también, como parte del proceso la producción de subjetividad, desde donde se organiza la percepción, el consumo, el disfrute de esos objetos culturales. Así, el consumidor de esos objetos percibe y clasifica aquello que ha sido preclasificado por la lógica de la producción de esos mismos objetos ${ }^{5}$. Todo esto logra confirmar la validez del sistema mediante la diluida frontera entre opuestos:

La reconciliación de lo universal y lo particular, de regla y pretensión específica del objeto, en cuya realización precisamente, y solo en ella, el estilo adquiere contenido, es vana porque no se llega ya a ninguna tensión entre los polos: los extremos que se tocan quedan diluidos en una confusa identidad, lo universal puede sustituir a lo particular, y viceversa (Horkheirmer \& Adorno, 1998, p. 174).

Así, la industria cultural se plantea como el estilo más inflexible de todos, en el cual se subordinan las distintas etapas de la producción en virtud de una misma idea rectora, el consumo; deviene de este modo en el objetivo del liberalismo, al que se responsabiliza por la falta de estilo. De este modo, "lo que se resiste puede sobrevivir solo en la medida en que se integra. Una vez registrado en sus diferencias por la industria cultural, forma ya parte de ésta como el reformador agrario del capitalismo" (Horkheirmer \& Adorno, 1998, p. 176).

Para los autores, la diversión implica entrar en el sistema con aprobación, anulando la capacidad de pensar y olvidar la realidad, incluso cuando se la muestra. En este sentido, implica una evasión del último pensamiento de resistencia, que esa realidad haya podido permitir aún. "La liberación que promete la diversión es liberación del pensamiento en cuanto negación” (Horkheirmer \& Adorno, 1998, p. 189); que no es otra cosa que la implicancia de la "eterna repetición de lo mismo" (p. 178). "Pero, fuera de esto, el abultado aparato de la industria de la diversión no hace, ni siquiera en la medida de lo existente, más humana la vida de los hombres" (p. 184) ${ }^{6}$.

5 En 1947, Adorno escribe un ensayo sobre la música pop, en el cual sostiene que, en la percepción de ese género, el oído anticipa lo que viene causando una "regresión". Entonces, el sujeto consumidor a partir de ciertos a priori, puede anticipar notas o algunos movimientos escuchando la composición musical. Esto hace que se refuerce la satisfacción personal. Adorno llama a esto "el efecto de reconocimiento", el principal efecto de la industria cultural. Le confirma al sujeto lo que ya sabía de antemano, y elimina la sorpresa y se impide toda producción de lo nuevo-genuino. Es ahí donde Adorno fundamenta la construcción de una "obra de arte autónoma".

6 Los autores consideran, que en este contexto los hombres solo son considerados en tanto clientes y empleados. "En cualquiera de los casos, ellos no dejan de ser objetos" (Horkheirmer \& Adorno. 1998, p. 191). Y más adelante afirman que en la industria cultural: "se combate al enemigo ya derrotado, al sujeto pensante" (p. 213). 
Ambos consideran que el triunfo sobre lo bello es realizado por el humor y por el goce en el mal y las privaciones ajenas. Y la risa, acompaña siempre al momento en que se desvanece un miedo, proclamando la liberación del poder. Por tanto, la broma emerge como un daño reconfortante, insumo indispensable de la industria de la diversión. Llaman a este momento la "estafa a la felicidad". "En la falsa sociedad la risa ha invadido la felicidad como una lepra y la arrastra consigo a su indigna totalidad. Reírse de algo es siempre burlarse" (p. 185). De este modo, el sistema presenta todas las necesidades como dispuestas a ser satisfechas por la misma industria de la cultura. Pero, al mismo tiempo, ese proceso productivo, organiza los roles de modo tal que, solo se experimente como eterno consumidor objeto de dicha industria.

\section{Escena 4. Las críticas de Adorno a Wagner}

Huyssen explica las críticas aclarando:

A la luz de la convicción de Adorno de que la mercantilización de la cultura de fines del siglo XIX prefigura la de la industria cultural y monta el escenario para la eficaz y productiva resistencia modernista de la mercantilización de las obras de Schonberg, Kafka y Kandinsky, parece lógico que Adorno intentara situar los gérmenes de la industria cultural en el arte elevado de finales del siglo XIX que precede al modernismo: Wagner, el Jugendstil y l'art pour l'art (Huyssen, 2006, p. 65).

En este sentido, Adorno discute los conceptos de l'art pour l'art, de Jugendstil y la música de Richard Wagner. En cada uno de estos casos, considera que su emergencia es un empobrecimiento en el interior de las formas de arte, un deterioro que conduce al testimonio de la creciente mercantilización de la cultura y prefigura de algún modo la industria cultural. Por esto, Adorno intenta situar sus orígenes en el arte elevado de fines del siglo XIX que precede al modernismo ${ }^{7}$. El propósito estético de la Gesamtkunstwerk solo era posible mediante una organicidad de los elementos internos de la obra. En perspectivas a posibilitar un todo; una única creación en la cual, las partes asisten a la composición. En Ensayo sobre Wagner, Adorno sostiene que

La apariencia que en Wagner alimenta si no crea la esencia, es al mismo tiempo la faceta que la obra de arte presenta hacia afuera, el "efecto". La apariencia no meramente se hace

7 Vale mencionar que la interpretación que Adorno hace de la obra de Wagner ocurre durante el momento del culto fascista a la obra del compositor. Este detalle no resulta menor, puesto que Adorno se distancia claramente de estas ideas. Por otra parte, el objetivo del Ensayo sobre Wagner, era analizar las raíces culturales y sociales del fascismo alemán. Dice: "Wagner comparte las ideas antisemitas con otros representantes de lo que Marx llamaba el socialismo alemán en torno a 1848" (Adorno. 2008, p. 24). El ensayo se publicó posteriormente en un libro titulado Monografías Musicales, donde también se incluyen los escritos: "Mahler. Una fisonomía musical" y "Berg. El maestro de la transición mínima". 
esencial, sino que, por lo mismo y necesariamente, la esencia se hace aparente; la integración de los elementos se produce a costa de la integridad de la composición (Adorno, 2008, p. 77).

\section{En Dialéctica de la Ilustración, Horkheimer y Adorno consideran que}

La industria cultural se ha desarrollado con el primado del efecto, del logro tangible, del detalle técnico sobre la obra, que una vez era la portadora de la idea y fue liquidada con ésta ... El efecto armónico aislado había cancelado en la música la conciencia de la totalidad formal; el color particular en la pintura, la composición del cuadro; la penetración psicológica en la novela, la arquitectura de la misma. A ello pone fin, mediante la totalidad, la industria cultural. Al no conocer otra cosa que los efectos, acaba con la rebeldía de éstos y los somete a la forma que sustituye a la obra. Ella trata por igual al todo y a las partes. El todo se opone, inexorable e independientemente, a los detalles ... La llamada idea general es un mapa catastral y crea orden, pero no conexión. Sin oposición ni relación, el todo y el particular llevan en sí los mismos rasgos. Su armonía garantizada de antemano es la caricatura de la armonía fatigosamente conquistada, de la gran obra de arte burguesa (Horkheirmer \& Adorno, 1998, pp. 170-171).

Ese "futuro" que necesita de un nuevo espectador para su nuevo arte, supone la importancia de la sumisión del individuo a la totalidad como un rasgo característico de la composición wagneriana y de su proyecto estético. En sus composiciones, los sonidos individuales ceden paso a favor de los complejos melódicos y armónicos que colaboran en la pérdida de los detalles. En el Anexo de Monografías musicales de 1952, Adorno aclara al respecto:

El principio más íntimo de este arte de instrumentación es que, gracias a las mixturas, a cada uno de los sonidos instrumentales ya no se les percibe su modo de producción ... Precisamente a través del arte de la mixtura y la duplicación se introduce en la instrumentación un elemento de lo superfluo, falso y decorativo que obstaculiza la unidad de la composición y sonido orquestal, por mor de lo cual, sin embargo, se desarrolló precisamente el arte de instrumentación de los sonidos mixtos ... La obra de arte wagneriana se define como un bien de consumo en el que ya nada debe recordar cómo se produjo. Se convierte en obra de magia en la medida en que el trabajo acumulado en ella aparece en el mismo instante como supranatural y sagrado, puesto ya no cabe reconocerlo como trabajo ... La obra de arte total busca borrar en la embriaguez los límites de las artes individuales en cuanto los momentos de su producción entre sí separados, y sustituir por una protounidad regresiva, irracional, la articulación consciente (Adorno, 2008, p. 488).

Al mismo tiempo, con lo anterior el drama wagneriano se instala como un producto acabado y no da cuenta del proceso de trabajo. Por esto, la crítica de la división del trabajo en obra wagneriana resulta nula. Adorno considera que, la desvalorización de lo individual frente al todo excluye la auténtica interacción dialéctica y se manifiesta de modo especial en la pérdida de los detalles. Al respecto, Huyssen ofrece un ejemplo: "La devaluación del individuo frente a la totalidad aparece en la orquestación de Wagner bajo la forma de una tendencia a ahogar 
la voz del instrumento individual a favor de un continuo de timbres y complejos melódicos en gran escala" (Huyssen, 2006, p. 79). Huyssen continúa su análisis diciendo que la modernidad de la alegoría y la disonancia en la obra de Wagner se compone de ese "simbolismo universal" que estimula una falsa totalidad y forja una monumentalidad igualmente falsa: la Gesamtkunstwerk. La totalidad se revela como mera apariencia, como contradicción elevada de lo absoluto. Por lo que, Adorno considera

El momento de la inautenticidad en la expresión wagneriana puede, por tanto, rastrearse hasta sus orígenes compositivos. Lo que en la forma se malogra afecta al contenido ... La música de Wagner finge la unidad en el interior y en el exterior, de sujeto y objeto, en lugar de dar forma a su brecha (Adorno, 2008, p. 38) ${ }^{8}$.

Se anulan las particularidades del proceso de composición de la obra. Aquello que debiera ser un fluir de matices en el llamado color de la música, aparece con la invariabilidad del todo, en un proceso de producción. El todo "se convierte en metáfora de lo infinito suprimiendo las contribuciones finitas que la constituyen, y la idea de su universalidad humana borra las huellas del trabajo vivo, de lo individualmente humano" (Adorno, 2008, p. 78). Aparece como un producto acabado, ocultando las huellas que posibilitaron su construcción, y descontextualizando su riqueza. El individuo moderno, en tanto aislado, no puede superar efectivamente la división del trabajo a la cual lo somete la Gesamtkunstwerk:

La división del trabajo de Wagner es la del trabajo de un individuo. Este le impone los límites, y quizá por ello aquélla debe reforzarse tanto en negarse a sí misma. ... la obra de arte total es sostenida por precisamente el "individuo" burgués y su alma, que deben su origen y sustancia mismos a esa alienación contra la que la obra de arte total protesta (Adorno, 2008, p. 104).

Adorno insiste en la importancia de las evidencias de la división del trabajo en la creación artística:

Las obras de arte deben su ser-ahí a la división social del trabajo, a la separación entre trabajo intelectual y físico. Sin embargo, con ello es como se presentan a sí mismas como serahí; su medio no es el espíritu puro, que es para sí, sino el que regresa a la existencia y en virtud de tal movimiento afirma como unido lo separado. Esta contradicción obliga a las obras de arte a hacer olvidar que son artificiales: la pretensión de su ser-ahí y por tanto la de ser-ahí mismo como la de algo pleno de sentido resulta tanto más convincente cuanto menos recuerda en ellas

8 "La obra de arte ya no obedece a su definición hegeliana de la apariencia sensible de la idea, sino que lo sensible se dispone para parecer como si dominase a la idea: éste es la verdadera razón del rasgo alegórico en Wagner, de la invocación de una esencialidad irrecuperable. ... El paso de la ópera a la soberanía autónoma del artista interfiere, por tanto, con el origen de la industria cultural" (Adorno, 2008, pp. 100-101). 
que han sido producidas, que son debidas al espíritu en cuanto algo exterior a ellas mismas. El arte, que ya no tiene la buena conciencia con respecto a tal engaño, su propio principio, ya ha disuelto aquel elemento en que solo él puede realizarse. En Wagner esa buena conciencia se ha extinguido y pese a todo su arte se aferra retrospectivamente a la pretensión de su ser-en-sí. Por eso debe exagerar esa pretensión y resaltar tanto más el falso carácter natural del producto cuanto más en la reflexión se ha desprendido de la naturalidad estética, cuanto más se ha entregado a lo artificial. La obra wagneriana encuentra en esto ese tipo de bienes de consumo del siglo XIX que no conoce más alta ambición que ocultar todo rastro de trabajo ... la apropiación del trabajo ajeno (Adorno, 2008, pp. 80-81).

Al mismo tiempo, cuando la obra de arte se convierte en "mágica" facilita en los hombres cierta veneración de su propio trabajo, puesto que no pueden reconocerlo como tal, en tanto que la obra de arte devenida en mercancía, es pura apariencia. Por todo esto, en Monografías Musicales Adorno caracteriza las óperas de Wagner comofantasmagoría, y analiza qué le sucede a la experiencia estética en la época de la mercancía, donde al borrarse las huellas del proceso de producción, se asemeja a la estética idealista.

La fantasmagoría, lo mismo que el ritmo de su declive, debe desplegarse en la obra de arte épica extensa. Su forma organizativa englobante es la obra de arte total o, como Wagner prefiere llamarla, el "drama del futuro", el cual reúne elementos poéticos, musicales y mímicos (Adorno, 2008, p. 92).

$\mathrm{Al}$ respecto, Huyssen comenta "en cuanto la mercancía comienza a invadir todos los aspectos de la vida moderna, entonces la apariencia estética se encuentra en peligro de transformarse en fantasmagoría, en la 'ilusión de la realidad absoluta de lo irreal'” (Huyssen, 2006, p. 81). Según Adorno, Wagner se rinde ante la presión de la mercancía. A diferencia del romanticismo clásico, Adorno reconoce que en las óperas de Wagner no hay "fantasmas reales", en cambio transfiere el componente mágico al alma humana9. Esto permite que se señale como verdadero, en tanto que, eleva la noción de saga o cuento. En la obra wagneriana, el concepto de ilusión deviene realidad absoluta de lo irreal.

Así como los bienes de consumo expuestos en la época de Wagner ya se vuelven seductoramente hacia las masas de compradores más que su lado fenoménico, y con ello hacen olvidar su carácter meramente fenoménico, es decir, su inaccesibilidad, así las óperas wagnerianas tienden a la mercancía en la fantasmagoría (Adorno, 2008, p. 86).

9 Adorno considera que la estilización de la obra de arte total, se manifiesta en las obras artísticas de la época de Wagner, en las que esos elementos genéricos cambian su función por la de artículos de consumo. "Dioses, héroes y acción planetaria prometen al anhelo estético la salvación basada en la huida de lo banal; el romanticismo temprano no había tenido necesidad de imágenes de la grandeza porque todavía no se encontraba a cada paso con la amenaza del carácter de mercancía del que luego acaban por adolecer también en Wagner los modelos heroicos" (Adorno, 2008, p. 99). 
En Teoría Estética también podemos leer:

La apariencia estética se incrementó en el siglo XIX a la fantasmagoría. Las obras de arte borraron las huellas de su producción; presumiblemente, porque el avance del espíritu positivista se comunicó, al arte que tenía que ser un hecho y se avergonzaba de lo que revelaba que su inmediatez estaba mediada. Las obras obedecieron a esto hasta bien entrada la modernidad. Su carácter de apariencia se incrementó hasta su carácter de absolutidad; esto se esconde detrás del término hegeliano de religión artística, que la obra del schopenhaueriano Wagner tomó al pie de la letra. La modernidad acabó revelándose contra la apariencia de la apariencia de no ser apariencial (Adorno, 2004, p. 141).

Además, Adorno explica que la fantasmagoría se da cuando los productos novísimos de la modernidad, se aproximan a lo antiguo bajo la imposición de sus propias limitaciones: "En la fantasmagoría, lo burguesamente nuevo y lo regresivamente primitivo convergen en la indiferencia" (Adorno, 2008, p. 90). Así, en la industria de la cultura lo idéntico se presenta como si fuera nuevo y sustituible y, al mismo tiempo, se desata "el proceso imparable progresista, que, sin embargo, no produce ninguna cualidad nueva y siempre vuele a desembocar en lo antiguo" (Adorno, 2008, p. 43).

De este modo, se presenta la fantasmagoría wagneriana que tiene considerables consecuencias: "Socialmente, la imbricación de lo viejo y de lo nuevo quiere que se ofrezcan sin cesar estímulos nuevos, sin nunca violentar los hábitos de escucha rutinarios" (Adorno, 2008, p. 49). Por esto, lo nuevo es al mismo tiempo lo antiguo. Huyssen comenta que, en cuanto fantasmagoría, la ópera wagneriana reproduce el mundo de ensueño de la mercancía bajo la forma de mito:

Con lo cual la obra de Wagner se hace profundamente ambigua en relación con su estrato temático mítico. Por otra parte, en él la intención mitológica persigue la ilustración consciente de la psicología individual y refrenda al individuo aparentemente autónomo de su dependencia a la totalidad. Por otro lado, los mitos mismos sirven a la regresión a lo antiquísimo en vano inalterable ... En Wagner la música delata el cuento de hadas en el mito ... La mitología conduce al conformismo ... Es el sino del idiosincrásico provocar idiosincrasia (Adorno, 2008, p. 490).

Considera que en la Gesamthunstwerk se funden lo mítico y el presente, en este último, el reino de las ideas y dioses wagnerianos. Mientras que, en el primero, la dimensión mítica invoca a la industrialización de la cultura. A este respecto, Huyssen sostiene "La Gesamthunstwerk es concebida como una poderosa protesta contra la fragmentación y atomización del arte y la vida en el interior de la sociedad capitalista. Pero, al elegir los medios equivocados, no puede sino fracasar" (Huyssen, 2006, p. 84). Agrega posteriormente que la totalidad de la música dramática de Richard es una falsa totalidad sujeta a desintegrarse desde su propio interior. Obras arrancadas de contexto, arregladas y convertidas en populares. Esta fragmentación de las partes posibilita la parcelación del todo. 
Otro de los rasgos que Adorno analiza es aquel que permite incorporar al público en la obra a través de efectos calculados. De este modo, Adorno entiende que el público toma el lugar de "objeto reificado del cálculo del artista" y de esto deviene las similitudes con la industria cultural. El esfuerzo del compositor-director en someter a su público, se asemeja al modo en que la ideología dominante de la cultura de masas somete a los consumidores:

Su música está más bien concebida para el gesto de marcar el compás y dominada por la imagen de marcar el compás. En este gesto, los impulsos sociales de Wagner devienen técnicos. Si en su época el compositor y la audiencia ya se oponen líricamente alienados entre sí, la música de Wagner tiende a paliar esta alienación implicando al público en la obra como elemento del "efecto" de ésta. Abogado del efecto, el director de orquesta es abogado del público de la obra. Pero en cuanto el que marca el compás, el compositor director de orquesta otorga a las exigencias del público una fuerza terrorista. El respeto democrático por el oyente se transforma en la connivencia con los poderes de la disciplina: en nombre del oyente se hace enmudecer aquello cuya sensibilidad se rige por normas distintas de la unidad métrica. En él desde el principio la alienación del público se alía con el cálculo del efecto sobre el público; solo una audiencia cuyo a priori social y estético se halle tan disociado del artista como en el altocapitalismo, deviene, reificada, objeto de cálculo de tratamiento artístico (Adorno, 2008, p. 31).

Esto mismo se pone, especialmente, de manifiesto en el peculiar leitmotiv wagneriano:

Adorno interpreta el doble carácter del leitmotiv como alegoría y propaganda. En tanto alegoría, el leitmotiv articula una crítica progresiva de las formas totalizadoras y de la tradición "simbólica" del idealismo alemán. Pero al mismo tiempo, funciona como propaganda, puesto que ha sido diseñado para recordarse fácilmente (Huyssen, 2006, p. 77).

En El Cine y la Música (1976), Adorno y Eisler destacan la importancia del leitmotiv en la obra de Wagner:

Sus éxitos masivos han estado siempre relacionados con la técnica del "leitmotiv": sus "leitmotiv" actuaban ya como una especie de marcas registradas en las que se podían reconocer figuras, sentimientos y símbolos. Fueron siempre la más vasta forma de ilustración, la falsilla para la gente sin formación musical. En el caso de Wagner se inculcaban a través de insistentes repeticiones, a menudo sin modificación alguna (Adorno \& Eisler, 1976, pp. 18-19).

Wagner intenta unir expresión y gesto en el leitmotiv secuenciable. "El contenido expresivo del motivo impide su repetición; pero en cuanto gesto solo se puede repetir, desarrollar. La música de Wagner lleva la canción y la danza a la indiferencia aparente" (Adorno, 2008, p. 485). El leitmotiv condiciona la construcción del motivo musical a favor de un discurso asociativo vinculado a estereotipos y situaciones recurrentes. Sin embargo, al mismo tiempo

entre las funciones del Leitmotiv se encuentra, pues, además de las estéticas, una mercantil, semejante al reclamo publicitario: la música está destinada, como posteriormente en 
la cultura de masas en general, a la retención, se la piensa de antemano para los olvidadizos (Adorno. 2008, pp. 31-32).

\section{Acto II. Las exposiciones secesionistas}

Las muestras secesionistas sin jurado constituían una actividad fundamental de la Asociación de artistas de las artes visuales en Austria; ofrecía a los artistas la posibilidad de exponer, y permitían al público ponerse al día acerca de las novedades del arte contemporáneo de Europa. De modo similar a la organización de la revista Ver Sacrum, las exposiciones también presentaban características de Gesamtkunstwerk: cada una de ellas estuvo a cargo de un artista diferente y, al mismo tiempo, respondían a un marco nuevo, tapizado, mobiliario, el cartel y todo tipo de decoración diseñada especialmente para la ocasión.

La primera fue realizada a los pocos meses de la conformación del grupo en los llamados Salones de Jardinería, con 131 obras de artistas extranjeros y 23 de artistas vieneses. La muestra debía posibilitar el intercambio con los centros artísticos extranjeros del arte moderno, una actividad que había sido descuidada hasta entonces. En aquella oportunidad, la confección del cartel estuvo a cargo de Gustav Klimt. Representaba la lucha del héroe griego Teseo contra el Minotauro, en vistas de la diosa Atenea; en esa composición, se reunía el objetivo de los artistas secesionistas: Teseo protegido por Atenea se dispone a luchar contra Minotauro. Este combate sería un acto de liberación de las artes y, en este sentido, se podría explicar como un acto político, habría ciertas similitudes entre la obra de arte y la realidad moderna de Viena de su tiempo. Al mismo tiempo, la lucha entre Teseo y Minotauro representaría también una revuelta de la generación de los hijos hacia los padres. La figura del padre estaría representada en el toro y la figura de la madre, como protectora, completaría el cuadro del triángulo de Edipo. Así, ella protege la revuelta del hijo contra el padre. Al mismo tiempo, el mensaje del cuadro constituye el propósito: fija el papel de la Secession como un movimiento cultural revolucionario, cuya meta es la superación de la cultura liberal paterna. De este modo, se revelan al conservadurismo de la Künstlerhaus a favor de la libertad del arte.

Atenea se encuentra presente en varias obras de Klimt; uno de los cuadros significativos, presenta a la diosa nacida con casco y lanza del cerebro de Zeus. En su pecho, se puede ver a Medusa -quien tenía el poder de convertir en piedra a quien mirase-y en su mano sostiene a una mujer de cabello rojo ${ }^{10}$.

10 Esta obra resume los temas más recurrentes de Klimt. En la composición se encuentran Atenea y Medusa: los opuestos escindidos de racionalidad e instinto, con sus características apolíneas y dionisíacas, recordándonos, que ambos conviven en lugar de excluirse. 


\section{Escena I: La muestra de 1902}

La XIV Exposición de la Secession, celebrada del 15 de abril al 27 de junio de 1902, es considerada como un momento central en la historia del grupo. Participaron veintiún artistas, que pusieron su obra al servicio de una idea general: "el Culto al Artista". El edificio de la Secession proyectado por Hoffmann, configuraba junto con las obras logradas exclusivamente para esa muestra, una Gesamtkunstwerk. Esta exposición fue un intento por plasmar la idea secesionista y consagrarla en un homenaje al compositor Ludwig Van Beethoven ${ }^{11}$, puesto que todas las composiciones se articulaban con la escultura de mármol policromado de Max Klinger. El propósito manifiesto de esta puesta en escena era proporcionar una experiencia de fusión artística; una verdadera caja de resonancia: arquitectura, música, pintura y escultura, todas ellas bajo una idea compartida. Por esto, la obra de arte solo era posible a partir de la interacción de las salas, los murales y la escultura.

La dinámica de las exposiciones vienesas secesionistas implicaba la destrucción de las composiciones después de finalizada la muestra. Sin embargo, el Friso es la única de las obras que fue conservada después de la finalización del evento. Las muestras formaban parte de un gran planteo efímero y constituía el experimento más importante de la obra de arte total. El día de la inauguración, Gustav Mahler (1860-1911) ${ }^{12}$ dirigió un arreglo para dos coros de la Novena Sinfonía de Beethoven en la magnífica instalación. Las exposiciones de los secesionistas -y de modo especial está dedicada a Beethoven- constituyen un paso fundamental en la historia de las exposiciones. En primer lugar, las obras no eran presentadas al público ordenadas según el artista o tema. Sino, eran reunidas en una obra de arte integral, en la que cada elemento estaba sometido al todo, a un contexto estético ideal y superador de las sumatorias de las partes. En segundo lugar, el marco arquitectónico de la exposición estaba en función de las obras presentadas, subrayaba y escenificaba la idea directriz, proponiendo un sentido general que permitía al visitante descifrar las obras individuales. Por estos motivos, las exposiciones de la Secession se asumían como puesta en escena de los propósitos estéticos wagnerianos de Gesamtkunstwerk.

11 Beethoven había muerto en Viena en 1827. En estos momentos, era una de las figuras de referencias del siglo XIX alemán. Por su parte, Richard Wagner le había dedicado varios escritos. El monumento de Klinger se proponía representar al compositor en el trono de Zeus, dando cuenta de algún modo de la admiración que generaba. El crítico Ludwig Hevesi comentó la organización de la muestra diciendo: "un lugar sagrado, un aire de templo para un hombre convertido en un dios".

12 La obra de este compositor y director de orquesta austríaco, se considera entre las más importantes del postromanticismo. 
Por su adhesión estética, el edificio de la Secession estaba concebido como un marco neutral revolucionando, así como la forma de la exposición. De este modo, podía transformarse de acuerdo a los requisitos de cada puesta en escena. Por ejemplo, mediante puertas corredizas era posible adaptar el espacio interior a las exigencias concretas. En las exposiciones de la Secession se destacan la esmerada concepción de las puertas que convierten en un acontecimiento el paso de una sala a la otra. Josef Hoffmann diseñó para la puerta de salida de la nave izquierda un relieve en forma de cuadrado completamente abstracto diseñado en argamasa, y es considerado como una de las primeras obras abstractas en la historia del arte.

El contexto particular de este nuevo evento generó considerables expectativas: hacía poco tiempo que se había producido el repudio a algunas de las composiciones de Klimt (los frisos diseñados para las Universidades habían sido rechazados, Medicina había sido presentada el año anterior) y los miembros de la Secession se habían solidarizado con él ante esta situación. Tanto el tema de la exposición ("El Culto al Artista"), como la forma y concepción de la misma eran intentos de la Secession por demostrar al público sus principios artísticos y político-culturales.

La exposición estaba concebida de forma que los visitantes no pasaban, directamente, a la sala principal en el centro de la cual se encontraba la escultura de Klinger. Antes eran conducidos por la nave lateral izquierda, donde podían observar las tres secciones, iluminadas desde arriba y decorada de modo discreto. En esa nave lateral, se encontraba el Friso de Klimt que, de algún modo, anticipaba el acontecimiento principal. La sala central podía ser contemplada desde las naves situadas a mayor altura. Allí se encontraban los murales El anochecer de Alfred Roller y El amanecer de Adolf Böhm que configuraban el contexto según el cual había que entender el significado de la obra principal y, por lo tanto, la idea de la exposición. Los visitantes abandonaban la instalación por la nave lateral derecha, la cual constituía un eco de la cuidadosa celebración. En ella se encontraban, entre otras, obras de Ferdinand Andri (Combatividad) y Joseph María Auchentaller (Alegría, la inspiración divina).

El edificio de Joseph María Olbrich debía posibilitar el placer estético liberado de lo trivial. Tal como escribía Hermann Bahr, periodista simpatizante de la Secession, el visitante tenía que "purificarse allí de lo ordinario, y prepararse para lo eterno", deshacerse de "las preocupaciones y caprichos del mundo vulgar" (Hermann Bahr citado en Gottfried Fliedl, 2006, p. 102). La exposición creada, concebida de acuerdo con aquellas condiciones especiales de la percepción y la presentación, debía ser apreciada como un ámbito casi sagrado en la que el arte había sido separado de la vida cotidiana. De esta forma, los edificios públicos monumentales dejaron de configurar el marco arquitectónico donde se desarrollaba el arte, para pasar a constituir un espacio más íntimo y privado donde se celebraba una exposición planeada para un 
corto periodo de tiempo. Hay que mencionar que esta escenificación de la experiencia estética no era realmente auténtica. La sacralización de la vivienda artística ya se había implantado con la idea burguesa del museo hacia fines del siglo XVIIIO. Después había sido suprimida por los museos clasicistas e historicistas.

La exposición articuladora de las diferentes artes rendía homenaje al gran compositor Beethoven y al escultor Klinger mediante la puesta en escena de la idea de Wagner que inspiró a la Secession: "liberar" a la sociedad a través del arte. De este modo, el artista se convertía en libertador; mientras que, a la obra de arte y su exposición en instrumentos de liberación. Schorske dijo de esta muestra: "Si alguna vez existió un caso de narcisismo colectivo, fue precisamente éste: artistas (la Secession) que ensalzaban a un artista (Klinger), quien, a su vez, rendía homenaje a un héroe del arte (Beethoven)" (Schorske citado por Gottfried Fliedl, 2006, p. 98).

\section{Acto III. El Friso de Beethoven}

Cerca de 60 mil visitantes se dieron cita en la muestra, convirtiéndose de este modo en uno de los éxitos públicos más importantes del art nouveau vienés. Originariamente, se había proyectado retirar el friso después de la exposición, por esto fue realizado con materiales baratos. Klimt lo pintó sobre una rejilla de madera cubierta con caña y enlucida. Para conseguir determinados efectos hizo uso de tachuelas, trocitos de espejo, botones y bisutería multicolor de cristal tallado. Con todo, el Friso se convirtió en un monumento que habría de perdurar sobre las otras obras de la exposición más reconocida de la Secession.

El Estado lo adquirió en 1970 y llevó a cabo una larga y costosa restauración ${ }^{13}$. Al mismo tiempo, hizo que se realizara una copia a escala para exhibir en las exposiciones; esta copia fue presentada por primera vez en Venecia en 1984. El original recién restaurado fue mostrado al público en 1986, en la exposición "Viena 1870-1930. Sueño y realidad". De este modo, el Friso de Beethoven se convirtió en una muestra monumental y en una de las más importantes creaciones austríacas -y quizá europeas-, del arte de fines de siglo XIX. Desde siempre, ha sido considerado como una pintura clave de la obra de Klimt y el hecho de que durante años no fuera accesible al público, le ha aportado una fama casi mítica. Posteriormente, fue reintegrado al edificio de la Secession aunque no a su lugar originario, sino en un sótano adaptado especialmente para su exposición permanente.

13 Cuando los socialistas se hicieron cargo del gobierno en 1970, el canciller Bruno Kreisky hizo una propuesta al propietario del Friso, Erich Lederer. La obra se encontraba en un estado desastroso, depositado en los sótanos de la Galería Austríaca. En 1974 comenzaron los trabajos de restauración por el Servicio Austríaco de Conservación de los Monumentos Nacionales. Esta tarea fue muy costosa, ya que fue realizado con materiales baratos considerando su planificada pronta destrucción. 
De acuerdo con el catálogo de la muestra, el tema central del Friso aludía al movimiento final de la Novena Sinfonía en re menor de Beethoven. El compositor habría empleado en su cuarto movimiento el texto "Oda a la alegría" (An die Freude de 1785, publicado un año después) de Friedrich Schiller. En este sentido, es parte constitutiva y estructural de la obra. Esta sinfonía es, quizás, una de las obras más populares y trascendentes del género clásico: presenta cuatro movimientos: Allegro, Scherzo, Adagio, y Recitativo; este último asume un final coral, inusual en la época. Para su composición Beethoven se inspiró en el poema de Schiller y, por esto, se podría considerar a la Novena Sinfonía como una puesta de Gesamtkunstwerk también, aún sin proponérselo.

En la introducción al catálogo, Ernst Stöhr explica que se propusieron crear un espacio unitario que pudiera ser adornado por manifestaciones pictóricas y escultóricas, al servicio de la idea espacial. Esto permitiría someter a las partes en una situación dada y dentro de un marco definido a favor de un efecto y una única idea general.

Max Klinger estaba dando los últimos retoques a la escultura de Beethoven. Esa esperanza de conseguir un contexto digno para el homenaje serio y magnífico que Klinger rendía a Beethoven con su escultura, era suficiente para originar esa alegría en el trabajo, a pesar de ser conscientes de que se creaba para muy pocos días, despertó una entrega total a la tarea propuesta. Así nació esta exposición que no debía estar marcada por la fugacidad de su existencia ... Queríamos sentir la felicidad que procura un trabajo con un objetivo y un destino determinados. Queríamos aprender. Todo ello debía hacerse realidad en una exposición, entre los límites de un edificio en el que no podía crearse nada permanente, puesto que toda exposición tiene que engullir forzosamente la obra de la anterior (Ernst Stöhr citado por Gottfried Fliedl, 2006, p. 98).

De este modo, el Friso de Klimt estaba pensado como decoración que, junto con otros elementos de la exposición, debía ilustrar de forma comprensible la idea general. Klimt no se enfrentaba aquí con una decoración monumental comparable a las de las primeras obras, donde la arquitectura y la decoración plástica imponían un marco fijo por adelantado, en el cual los cuadros se incorporaban de modo superpuesto. En esta dinámica, en cambio, tenía la posibilidad y la necesidad de incluir la composición pictórica y sus instrumentos creativos dentro de un concepto general, espacial y temático. También significaba poder decidir con libertad sobre la concepción artística del mural dentro del marco que le proporcionaba el edificio de la Secession.

La creación de ese espacio unitario era el objetivo determinado, la escultura y la pintura asistían esa idea espacial compartida. Las partes se sometían al efecto del conjunto, dentro de esa idea global. En este caso, el Culto al Artista; la religión del arte, como aquello más valioso que puede desarrollar el hombre. Pero toda esta intención creadora parte del deseo; un deseo de trascendencia por el cual el hombre da forma a su paso por este mundo y supera los límites de la pintura habitual. Todo este montaje ha sido concebido en el sitio más propio del grupo: al 
interior de las paredes de su propia casa, aquel edificio secesionista protagonista del arte moderno vienés que con esta puesta en escena intentó la revalorización del espacio interior de la composición. Este impulso creador encuentra su justificación en la obra de arte de Max Klinger que aparece como aglutinante de la instalación. La misma es concebida como un homenaje serio y digno al artista ante el cual se ofrece el culto. La obra de Klinger motivó alegría en la realización de la instalación secesionista entorno a su creación y otorgó un objetivo determinado a las composiciones más allá de la fugacidad de la muestra. A pesar de esto, la entrega secesionista fue total y no estuvo marcada por la temporalidad de su existencia. Fundamentalmente, el conocimiento de un objetivo compartido generó felicidad en la realización del trabajo y se refieren a esto en términos de aprendizaje. La puesta fue realizada en los límites de un edificio en el cual nada podía ser permanente, ya que toda nueva muestra debía sobreponerse a la anterior en el espacio. El primer cuerpo del Friso se conoce como El ansia de la felicidad, con estas palabras se explica en el mencionado catálogo:

El ansia de la felicidad. Los sufrimientos de la débil humanidad. Los ruegos de la misma a la fortaleza, armada con la compasión exterior y la ambición interior como fuerzas motrices que la llevan a emprender la lucha en busca de la felicidad (fragmento del catálogo citado por Gottfried Fliedl, 2006, p. 105).

Por su parte, en la pared transversal estaban representadas Las fuerzas enemigas, el segundo momento de la composición de Klimt:

El gigante Tifeo, contra el que los mismos dioses lucharon en vano, sus hijas las tres gorgonas, enfermedad, locura y muerte. Lujuria e inmortalidad, intemperancia y dolor profundo. Las ansias y deseos de los hombres se encapan por encima de ellas (fragmento del catálogo citado por Gottfried Fliedl, 2006, p. 105).

La transición a la tercera escena es constituida por una serie de figuras que parecen flotar libres sobre el fondo enlucido apenas sin retocar. Finalmente, en la pared longitudinal se presenta el desenlace de la lucha, en El ansia de la felicidad se calma con la poesía:

El ansia de la felicidad es saciada en la poesía. Las artes nos conducen a un reino ideal donde solo podemos encontrar alegría pura, felicidad pura y amor puro. El coro de los ángeles del paraíso. "Alegría inspiración divina". "Ese beso para todo el mundo" (fragmento del catálogo citado por Gottfried Fliedl, 2006, p. 105).

Hermann Bahr considera que el Friso aborda el tema del genio compartiendo, de este modo, la inspiración metafísica de la obra de Klinger. A diferencia de las demás creaciones logradas para la exposición, que se caracterizan por ser figurativas con un carácter más bien decorativo o didáctico, Klimt se propone representar la religión estética profesada por los secesionistas y la salvación de la humanidad a través del arte. En otras palabras, que hacía referencia 
a la liberación de la "débil humanidad" a través del arte y el amor, siguiendo al mismo tiempo, los propósitos estéticos de Richard Wagner.

En las antiguas fotografías de la exposición se puede reconocer que las tres partes del Friso estaban, originariamente, separadas por delgadas bandas de pared. Por lo cual, se deduce que la obra no narra una historia continua, sino que configura una serie de escenas, referencias alegóricas a la idea de la liberación por medio del arte que se ilustraba con la escultura de Beethoven en el centro de la exposición. Se entiende, por tanto, que su lectura no es necesariamente lineal. Más bien plantea una posibilidad de interpretación dinámica, abierta y relacional, tal como considerar elementos contextuales como el arreglo de la Novena Sinfonía en una banda citadina - con solo instrumentos de viento- dirigida por Gustav Malher.

Poesía, música y artes de espacio como la arquitectura, la pintura y la escultura, asisten a un mismo impulso creativo: la posibilidad de la salvación del hombre por medio del arte. A este es el propósito estético al que respondían los secesionistas, el proyecto estético wagneriano. La disposición klimtiana de la Novena Sinfonía no es para nada caprichosa, se adaptaba a la lectura ofrecida en el año 1846 por Richard Wagner sobre la composición de Beethoven. En una de sus ejecuciones, Wagner se valió de algunas citas de Goethe para nombrar las sensaciones inspiradas por la música. Así, en relación al Scherzo, el segundo movimiento, usó estas palabras: "voluntad salvaje... embriaguez del goce doloroso" en las que se hace presente de modo necesario el intercambio de angustia y placer. Esto establece una estrecha vinculación con el contenido dicotómico que reconoce Nietzsche en la tragedia griega y en toda creación artística. Klimt parece traducir estas palabras wagnerianas en imágenes con alto poder expresivo. La admiración a Beethoven propia de la época da cuenta de la elección temática de la instalación; la escultura de Klinger es el impulso creador que motiva la necesidad de un contexto digno en los secesionistas.

\section{Acto IV. La mujer en la composición de la industria de la cultura}

Los trazos interpretativos de la obra descripta son inagotables. Una de las entradas posibles es recorriendo la figura femenina que encarna el deseo de expresión de Gustav Klimt. A continuación, se intentará una aproximación a ello.

\section{Escena I. Lo femenino en Klimt}

Si bien no se puede identificar un solo estilo en su obra, la mujer es sin duda una constante en sus composiciones. En su extensa obra, Klimt aborda temas de inspiración universal tales como la vida, la muerte, el amor, las relaciones humanas, la melancolía por el irreversible paso del tiempo, la belleza, el dolor, el placer; pero todos ellos encarnados en una figura recurrente: la mujer. Al momento de su muerte, se encontró en su taller numerosos apuntes y 
esbozos a lápiz de dibujos eróticos. Sin duda, una de sus más recurrentes fuentes de inspiración ha sido el desnudo femenino. Vale mencionar que, en sus dibujos a lápiz se encuentran mujeres ancianas, con cuerpos ajados y desnudos.

Lo cierto es que, salvo excepciones, solo retrató mujeres y sus personajes alegóricos se representan por medio de figuras femeninas. Es por ello que la recurrencia de la mujer en su obra no puede obviarse. La mujer en Klimt es personaje de la vida y de la muerte, peligro y salvación, al mismo tiempo. Las mujeres se representan de diversos modos y encarnando diversas facetas de la vida; sin embargo, se reconoce la predominancia de un tipo de mujer agresiva y dominante que los críticos relacionan con el modelo icónico de la femme fatale. Más allá de lo erótico, las mujeres en Klimt parecen estar encerradas en sí mismas, permaneciendo ajenas a la mirada del observador. Por ello, quizá, se presentan desinhibidas, como si no advirtieran que están siendo vistas en su intimidad y misterio. El contexto de liberalismo perfora también los tabúes sexuales y se pone de manifiesto en la obra klimtiana.

\section{Escena 2. Industria cultural, cultura de masas y lo femenino}

La cultura de masas de siglo XIX está de algún modo ligada a la mujer, en tanto que, la cultura auténtica y "elevada" se encontraría reservada a los hombres. Por esto, cabe preguntarse: ¿por qué Gustav Klimt se detiene particularmente en pintar mujeres alrededor de la fi-

gura del "genio"? En este caso Beethoven, representado como una bestia. ¿Qué lugar le otorga a esa presencia femenina? ¿Puede tener relación con la incipiente cultura industrializada que reconoce Adorno?

La mercantilización de la cultura de fines del siglo XIX, de algún modo posibilita que Adorno (2008) ubique los orígenes de la industria cultural en Wagner y en l'art pour l'art, como se desarrolló anteriormente. La auto-justificación del arte moderno y la emancipación que adquirió luego de romper las cadenas con la Iglesia y el Estado devino en la lectura de Adorno en un empobrecimiento de sus estructuras internas del arte elevado, un deterioro que conlleva el testimonio de la mencionada creciente mercantilización de la cultura. En Teoría Estética Adorno (2004) plantea que el concepto de belleza de los movimientos estéticos modernos, tales como l'art pour l'art, Jugendstil, art nouveau, se encuentra extrañamente vacíos, sin embargo, paradójicamente resulta el tema elegido. De este modo, plantea la imposibilidad de la belleza por determinarse a sí misma, en tanto que solo consigue hacerlo por medio de otro. En esa misma obra, Adorno expone que, por sus características latentes de mercancía, el arte moderno está condenado a vivir como kitsch, un objeto que se asemeja a los concebidos para la diversión.

El arte moderno de Klimt no puede pensarse por fuera de estas consideraciones teóricas, su emergencia da cuenta de la consolidación de un estilo protagonista de las escisiones 
modernas que se encarnan en la cultura a principios de siglo XX. Entonces, Adorno sugiere que los procesos sociales que dan forma a la cultura de masas no deben estar escindidos de las obras de arte más logradas. Por tanto, cualquier análisis del arte modernista o pre-modernista, evidenciará huellas de estos procesos en la trayectoria de los propios materiales estéticos. Aquí emerge un primer desencuentro -fundamental- entre la teoría frankfurtiana de Adorno y el propósito estético moderno encarnado en las obras de la Secession: la ideología de la autonomía de la obra de arte confronta con la afirmación de que ninguna obra de arte puede sustraerse de lo social.

Ahora bien, ¿de qué modo se entiende la incipiente industrialización de la cultura en relación con las manifestaciones femeninas de la composición? ¿Habrá acaso alguna relación entre el modo de ser klimtiano de las mujeres con estas críticas adornianas respecto de la posibilidad de una prehistoria de la industria cultural en el Imperio Austro-Húngaro de principios del siglo XX? Para el compositor alemán Richard Wagner, la Gesamtkunstwerk es posible en tanto que se manifieste la fusión de las artes en un contenido concreto e individualizado. Además, considera esa unión solo posible mediante el amor que vehiculice adecuadamente la expresión; sería un amor hacia la idea dramática a la que todas las artes deben asistir la que posibilitaría esa organicidad en la composición (Wagner, 2011). Ahora bien, en este planteo amoroso se describe de modo metafórico la música en el papel de la mujer que se entrega, que cede su deseo a un único propósito e idea que le deviene rectora.

Así, se supondría que la naturaleza habría portado de belleza a la mujer y al hombre de fuerza y de conducción para disfrutarla. En la obra de Gustav Klimt la mujer no es solo la musa, sino también el canal de expresión de las motivaciones masculinas -liberales- más profundas y sinceras. También en la modernidad, la masculinidad aparece ligada con la acción, la iniciativa y el progreso, el terreno de los negocios, la industria, la ciencia y la ley. Todo esto es reforzado por la cultura patriarcal burguesa que mediante estos modelos se erige como la auténtica. Al recorrer las obras de Gustav Klimt, resulta evidente que la mujer se hace presente de modo excepcional en sus creaciones. Sin embargo, en esta etapa de su obra surge un tipo de mujer particular que se presenta de diversos modos. Así, se sirve de la ductilidad femenina lograda en su obra para ambientar diferentes climas en la composición. Por ejemplo, los usos de la figura femenina en los laterales izquierdos aluden a las formas suplicantes, se presentan también en la procesión de la humanidad, en la niña arrodillada y en la pareja que suplica al caballero con armadura. Sin embargo, el hombre que constituye la pareja, se mantiene siempre por detrás de la figura de mujer. Ella asume el encargo, en ese dúo ella parece tomar la iniciativa.

Del mismo modo, en Las fuerzas hostiles rodeando la figura del monstruo romántico Tifeo, se crea un acompañamiento envolvente del protagonista, también masculino, por medio de la presencia de Enfermedad, Locura, Muerte, Angustia, Lujuria, Impudicia, Desmesura, 
Dolor Profundo y una serie de demonios ensimismados que también son figuras femeninas. Las alegorías en este caso toman forma de criaturas femeninas y representan un tipo de femme fatale que resulta recurrente en Gustav Klimt. Sus cuerpos portan una densa sensualidad en sus gestos, cabellos, miradas y posturas: el deseo y el temor aparecen como grandes motores.

Simultáneamente, en la tercera pared se recurre nuevamente a la figura femenina como en toda la composición, a excepción del lugar protagónico: en el Beso que encarna la representación de la plenitud de la felicidad, solo se ve aquel caballero que conquistó para la humanidad el sueño romántico del todo. Sin embargo, aquí las mujeres son nuevamente imprescindibles y despojadas de la connotación maligna y amenazadora de la pared anterior. La repetición de posturas, rostros, y actitudes otorga al conjunto un ambiente ritual en el cual las figuras femeninas se presentan con cierto carácter estático.

Como se mencionó anteriormente, Gustav Klimt compone este Friso a partir de la lectura que Richard Wagner hace de los versos de Friedrich Schiller, así, una clave divina a la poesía romántica. Quizá por ello, el abrazo de la pareja evoca cierta noción de sacralidad, en tanto que el Coro de Ángeles aparece protegido por una gran campana. Desde este punto de vista, el verde y las flores que pisan esas figuras, representarían el Edén, al que solo se podría acceder por medio de la "religión del arte". Richard Wagner entendía la experiencia estética como una unión necesaria de amor, el cual sería universal y posible por medio de la organicidad estética, de ella se desprendería la más pura de las alegrías (Wagner, 2011). Así, se advierte que en la composición del Friso las fuerzas del bien se encarnan en la composición en la figura masculina del caballero. Sería una muestra narcisista de la ideología hegemónica que representaba el grupo de Gustav Klimt, puesto que el artista no se presenta como un luchador colectivo de la felicidad.

Si bien el caballero tiene una armadura, el conflicto armado con las fuerzas enemigas no tiene lugar en la composición. En el momento final, es el héroe únicamente quien es redimido. Por esto no se trata de un protagonista agente y colectivo, sino, una figura individualista que de modo particular asume la misión. Entonces, el tema del relato pictórico no es la lucha o el enfrentamiento con las llamadas Fuerzas hostiles, más bien, el Friso de Beethoven ratifica el rol del hombre dentro de la realidad social moderna: un sujeto que, habiendo sido escindido, es protagonista de una experiencia empobrecida de sufrimiento y resistencia individuales y, como tal, no puede generar un proceso de emancipación social genuino, auténtico para la humanidad suplicante de la primera composición.

El individuo moderno hacedor de esta obra es un burgués que, como tal, desconoce la cosa en sí, puesto que, como Lukács explica, asumir la conciencia de ello lo conduciría a un replanteamiento del sistema del cual forma parte privilegiada (Lukács, 1970). Por todo esto, 
el individuo burgués protagonista de la composición -luego de atravesar Las fuerzas hostilesno solo afirma su posición social de privilegio, sino que también reafirma su identidad como sujeto masculino en la sociedad, luego de haber perforado las presiones concretas a las que lo somete la misma sociedad burguesa que le otorga su posición.

Al mismo tiempo, lo que amenaza la identidad del caballero se contiene en la pared más angosta. Las fuerzas hostiles son figuras femeninas, a excepción de Tifeo, que representan características de las crisis individualistas del liberalismo moderno. Por medio de su sexualidad representan, de algún modo, la naturaleza instintiva de la mujer como auténtica fuerza enemiga, indomable y desenfrenada. Pero son también figuras femeninas las que conducen y envían al héroe a la plenitud. Sin embargo, ellas se caracterizan por ser puras, sanas y morales. Así, el hombre se libera a sí mismo y no a la humanidad. El héroe alcanza su liberación cuando se aleja de las figuras femeninas que lo guían y, por tanto, de la naturaleza instintiva femenina. Al mismo tiempo que esto le permite dominar la suya; puesto que el aspecto agresivo se proyecta en la mujer. Por lo anterior, las diversas formas de amenaza se presentan como figuras femeninas que surgen precisamente de los temores masculinos burgueses modernos.

Finalmente, el conflicto planteado por el Friso encuentra una resolución temprana y conclusiva. Las fuerzas enemigas se escapan flotando y se alejan del enfrentamiento que no ocurre. Esta resolución casi milagrosa o mágica, se asemeja a los finales que Adorno reconoce en los dramas de Wagner. Al mismo tiempo, se presenta la debilidad masculina que solo en la fantasmagoría encuentra una resolución a su falta de dominio de la realidad, uno de los mitos más fuertes de la modernidad. Así, los deseos y las ansias permiten evitar el conflicto. Además, al estar depositados en la figura femenina se logra la plenitud masculina. El miedo en este caso, se aleja cuando el hombre deposita la causa en la mujer.

En la tercera pared, una pareja ocupa el centro de atención; el caballero se ha despojado de su armadura y abraza a una mujer que permanece oculta. No pueden verse sus rasgos puesto que permanece de espaldas al espectador. Ese beso, también representa la liberación del hombre por medio de la mujer. La figura del hombre desnudo cubre casi por completo a la figura femenina. Ambos se funden en una individualidad que deviene en una unidad forzada e indisoluble. La mujer en las composiciones aparece como objeto de inspiración del hombre, también para Klimt, en cambio el sujeto masculino emerge como creador de una obra genuina y auténtica.

La "liberación" que consigue el caballero para sí, se asemeja a una huida de la realidad por medio del arte, una fuga de la vida que se hace posible en la experiencia estética. Esa es acaso la mejor representación del arte moderno; que pretende para sí una auto-justificación. En el modernismo estético conviven los defensores de la autonomía estética junto con la expansión 
de la cultura de masas en todos los rincones de la esfera social. El proyecto modernista ha intentado ocultar la cultura de masas que ha sido generada por él. Por tanto, parecería que la cultura de masas está asociada a la mujer en tanto que la cultura elevada, auténtica y real es característica de los hombres. La cultura moderna de masas resulta impuesta y administrada desde arriba, en una sociedad manejada por los hombres, de forma que la masificación se asocia más con lo femenino. Esto mismo acentúa la dicotomía alto/bajo, vinculando lo primero con el hombre y lo segundo con la mujer. Resulta notorio que, la identificación de la mujer con la cultura de masas tiene implicancias políticas. Así, hacia fines del siglo XIX, la imagen que la sociedad tenía de la mujer le servía de proyección para todos los miedos y angustias, como vimos en el Friso de Beethoven.

En la obra, Klimt no aísla las mujeres de la narración, sin embargo, logra cierta armonía en un distanciamiento de las mujeres respecto del espectador; ellas no dirigen sus miradas al encuentro de quien mira, sino que permanecen distantes como si no advirtieran la presencia del otro, como se mencionó antes. El dibujo y el espectador se aíslan, las mujeres aparecen con los ojos cerrados o con la mirada desviada. En la composición no existe una comunicación directa entre las mujeres representadas y el espectador. Este hecho concede a las mujeres una autonomía peculiar: el espectador tiene la sensación de que solo están determinadas por sí mismas y sus sensaciones. Entonces, su imagen puede construirse independientemente de la presencia del espectador y al mismo tiempo, existir al margen de su mirada. Desde este punto de vista, son mujeres que no dependen de la mirada del artista o espectador para ser. En cambio, parecen disponer libremente de sí mismas, de su cuerpo y su sexualidad. Al mismo tiempo, se afirma que solamente mediante el erotismo y la sexualidad podrían alcanzar la autonomía, único y último modo.

En la composición, el varón nunca pierde el dominio sobre sí mismo, aun cuando parece experimentar el placer. Al mismo tiempo, se logra la despersonalización de la mujer. La distancia y el aislamiento tienen, además, la función de proteger al espectador -masculino- y al artista frente a la experiencia estética. De este modo, la mujer se convierte en objeto manteniendo así la separación entre los sexos. Así, se refuerza la disposición del hombre sobre la mujer, tanto en el proceso creativo como en la contemplación. El hombre burgués moderno se protege de cuestionar su identidad. En contraposición, ataca la identidad de la mujer, al reducirla a un ser de naturaleza erótica.

Klimt se sentía atraído por lo femenino; pero lo que le interesaba era el cuerpo como estímulo erótico, pero no la femineidad en sí. Lo que cautivaba su atención era lo femenino en el cuerpo de la mujer, en muchos casos el cuerpo en un sentido claramente sexual. Desde esta perspectiva, se entiende que se plantee de modo fragmentario la noción de femineidad, puesto 
que se trataría de una fragmentación estética del cuerpo humano. De este modo, la fragmentación altera la integridad, en este caso, de la mujer y al mismo tiempo, fortalece la mirada masculina burguesa dominadora.

Ahora bien, si Klimt logra que el espectador reduzca la noción de femineidad a determinados aspectos sexuales y mediante instrumentos formales redirige la percepción de las mismas, sería una posibilidad que conlleva su antítesis. Se pone en evidencia una sexualización del cuerpo, pero esta fragmentación del cuerpo, también se proyecta en el sujeto. Con esto se asume que, del desnudo femenino, surgen muchos de los temas en Klimt: la mujer se presenta pasiva y allí se pone a disposición de la experiencia creadora. Pero, también emerge en escena la transformación de la persona en materia, en una cosificación que deviene de una experiencia empobrecida de la vida. Klimt disponía sobre la mujer no solo como parte del proceso creativo, sino también montaba lo material como fuente de forma. Por esto, la mujer en la composición no hace el arte, pero sí al artista. Así, Klimt recompensa a su mentora -la mujer-creando un mundo con su forma (Gottfried Fliedl, 2006).

\section{Escena 3. Una hermenéutica de la mujer en Klimt. Juego, símbolo y fiesta}

Siguiendo a Gadamer, se asume que ningún marco interpretativo puede pretender la condición de objetividad en su recorrido. Este trabajo intenta problematizar la noción de mujer en el Friso de Beethoven reconociendo la imprescindible fusión horizóntica entre el artista, el mundo representado y nuestra mirada, que se asume contemporánea a la misma. Es esa misma noción de juego (Gadamer, 1998) que emerge del acto interpretativo cuando se entra en el círculo hermenéutico que fusiona las historicidades. En el proceso reconocemos a un otro en la experiencia estética, un ser como símbolo que resulta un fragmento en la cadena infinita de significantes con los cuales nos rodea el mundo. Desde este punto, cabría pensar entonces en los alcances y significados de la identificación del mundo de Klimt con la imagen de lo femenino. Las figuras de mujeres presentan parte del conflicto de Klimt; el aislamiento de las figuras, las formas caprichosas con las cuales se configura su propio espacio, el ensimismamiento, pasividad y aislamiento de las mujeres. Por ello, se advierten cerradas, distantes de la figura del espectador, como en un estado de ensoñación.

Se pone en escena la imagen femenina del mundo al que Klimt aspira como realización de la plenitud de la felicidad que es promesa del arte. Al mismo tiempo, la sensibilidad erótica femenina se logra por medio de la obsesión del artista masculino que, ante la crisis liberal de la identidad de su género, buscó una identidad femenina. En esta composición se reconoce la presencia de la dualidad tan clara que se manifiesta longitudinalmente en su obra completa; la presencia de un despliegue o desdoblamiento de la imagen de la mujer en una erótica, la llamada 
femme fatale y la magna mater, por un lado. Por otro, la mujer idealizada de la alta sociedad. En parte, las figuras femeninas asumen roles antagónicos en la composición. Ellas no son las que deben ser liberadas, sino que aparecen como formas del mundo, situaciones en el devenir del protagonista, que es masculino, burgués y artista. Entonces, la mujer aparece como virtuosa, pura y moral. A la vez que se presenta como la antagonista por excelencia del aquel hombre burgués que busca su felicidad. Este desdoblamiento manifiesta de algún modo la escisión del sujeto moderno, el uso de una moral pública y una privada; la dualidad que se pone en juego en la realidad social burguesa. Esta misma dualidad, se presenta en muchas de las obras de Klimt; la mujer como ser mítico -brujas, genios marinos-y las mujeres burguesas.

La noción de masculinidad moderna burguesa, se consolida en tanto que refuerza las dicotomías planteadas en la identidad femenina. Por ello, la mujer como maligna y como benevolente, "hembra" y "dama", "prostituta" y "madre", se expresa en las figuras femeninas del Friso. Desde este punto de vista, se plantea la convención que da cuentas de los roles sociales, en tanto que son imágenes producidas por el miedo del varón moderno burgués. Si como explica Adorno, "la organización de la obra de arte total ... solo podría pensarse como colectiva" (Adorno, 2008, p. 489), el Friso de Beethoven no únicamente ilustra el propósito estético wagneriano de la liberación de la humanidad a través del arte y el artista, sino también da cuenta de la individualidad que es protagonista de la era moderna. Sin embargo, no se trata de cualquier individualidad, sino de una individualidad masculina burguesa moderna. Estos diálogos hermenéuticos acerca de la mujer en la obra de Klimt permiten poner en evidencia la tradición, el otro y nosotros mismos, en la medida que nos asumimos como una subjetividad contemporánea de aquello que sale a nuestro encuentro en la interpretación. La noción de fiesta es aquella que nos permite advertir una variación en la temporalidad de nosotros mismos.

\section{Referencias}

Adorno, T. W. (2008). Monografías musicales. Madrid: Akal.

Adorno, T. W. (2004). Teoría estética. Madrid: Akal.

Adorno, T. W. \& Eisler, H. (1976). El Cine y la Música. Madrid: Fundamentos.

Agamben, G. (2008). ¿Qué es lo contemporáneo? (Traduc. Ariel Pennisi) Recuperado de http://19bienal.fundacionpaiz.org.gt/wp-content/uploads/2014/02/agamben-que-es-locontemporaneo.pdf

Foucault, M. (1999). La verdad y las formas jurídicas. En Estrategias de poder. Obras esenciales. Volumen II. Barcelona: Paidós.

Foucault, M. (2009). El gobierno de sí y de los otros: curso en el Collège de France: 1982-1983 (1 
ed.). Buenos Aires: Fondo de Cultura Económica.

Foucault, M. (2008). El poder psiquiátrico. Curso en el Collège de France 1973-1974. Buenos Aires: Fondo de Cultura Económica.

Foucault, M. (2008). El poder psiquiátrico. Curso en el Collège de France 1973-1974. Buenos Aires: Fondo de Cultura Económica.

Gadamer, H-G. (2006). Estética y Hermenéutica. Madrid: Tecnos

Gadamer, H-G. (1998). La actualidad de lo bello. Buenos Aires: Paidos.

Gadamer, H-G. (2004). Verdad y Método II. Salamanca: Síganme.

Gottfried, F. (2006). Klimt. Madrid: Ed. Taschen

Grüner, E. \& Gómez, R. (2009). Consideraciones en torno al legado teórico de la Escuela de Frankfurt. En el curso: La escuela de Frankfurt: controversias sobre su legado teórico (Programa Latinoamericano de Educación a Distancia, Centro Cultural de la Cooperación Floreal Gorini, Buenos Aires).

Horkheimer, M. \& Adorno, T. (1998). Dialéctica de la Ilustración. Madrid: Editorial Trotta S. A.

Huyssen, A. (2006). Después de la Gran División. Modernismo, cultura de masas y posmodernidad. Buenos Aires: Adriana Hidalgo Editora

Lukács, G. (1970). Historia y Conciencia de Clase. La Habana: Instituto del Libro.

Nietzsche, F. (2003). Sobre la utilidad y el perjuicio de la historia para la vida. [II Intempestiva]. Madrid: Biblioteca Nueva.

Nietzsche, F. (2009). Sobre verdad y mentira en sentido extramoral y selección de fragmentos. En: Sobre verdad y mentira. Buenos Aires: Miluno.

Nietzsche, F. (2008). El Nacimiento de la Tragedia. Buenos Aires: Caronte Filosofía.

Ortega, I. (2009). Ángel Ferrant y la Escuela de Artes y Oficios de Vienal. En Pulso. 32, 25-53

Rojas, I. R. (1999). Theodor W. Adorno y la Escuela de Frankfurt. Convergencia. Revista de Ciencias Sociales, 19 (VI), 71- 86.

Schmucler, H. (1997). Memoria de la Comunicación. Buenos Aires: Editorial Biblos.

Vignale, S. (2010). Las luces y las sombras. Lecturas de Michel Foucault y Giorgio Agamben sobre la cuestión del presente. En Susana Barbosa y Celina Lectora (Coomp.) y Cecilia Pisarello (coord.), El bicentenario ante el transhumanismo y la cultura cyborg. Actas Jornadas Nacionales de Antropología Filosófica. Buenos Aires: Ediciones Fepai. 
Artículos

Vignale, S. (2010). Cuidado de sí, cuidado del otro, aportes desde M. Foucault para pensar la educación. Contrastes. Revista Internacional de Filosofía, 18, 307-324.

Wagner, R. (2011). El arte del futuro. Buenos Aires: Prometeo Libros. 